\title{
Filozofia a problem uchodźców w Niemczech
}

Jan P. Hudzik

TEKSTY DRUGIE 2017, NR 2, S. 280-300

DOI: $10.18318 / \mathrm{td} .2017 .2 .16$

$\mathbf{D}_{\mathrm{d}}$ wieście lat po Kancie niemieccy filozofowie podobnie jak on zabierają głos w debacie publicznej na temat uchodźców. Debata ta staje się czymś więcej niż tylko zwykłą dyskusją o bieżących problemach politycznych i społecznych związanych z masowym napływem przybyszów z dalekich krajów. Mianowicie, wpisuje się ona w powojenny dyskurs tożsamościowy Niemiec. Filozofowie zawsze brali w nim aktywny udział. Polskiego czytelnika może to dziwić, zważywszy na rodzimą sferę publiczną, ujmując rzecz oględnie, mało otwartą na głos intelektualistów. Nasi zachodni sąsiedzi dają nam więc wyjątkową okazję, by na gorąco przyjrzeć się ich (filozofów) publicznym wystąpieniom i spróbować odpowiedzieć na kilka pytań.

Jedne z nich dotyczą samej filozofii: jak można lub należy rozumieć relacje między nią (teorią) i praktyką społeczną? Inne pytania są już natury politycznej i moralnej, jak przykładowo te oto: czy obrona partykularnego - tu: kultury narodowej - musi oznaczać automatycznie odrzucenie uniwersalnego, wsparcie dla ideologii nacjonalistycznej? Jakie są relacje między gościnnością
Jan P. Hudzik filozof, profesor Uniwersytetu Marii Curie-Skłodowskiej w Lublinie, zajmuje się problemami z obszaru filozofii kultury, polityki, sztuki, mediów, historii idei, metodologii oraz teorii nauk społecznych i humanistycznych. Wydał m.in. Niepewność i filozofia (2006), Trzy studia o metafizyce, pamięci idemokracji (2009), Prawda i teoria (2011). 
i prawem stanowionym, czyli prawami człowieka i obywatela? Alasdair MacIntyre zdaje się być dobrym przewodnikiem po komentarzach do takiej debaty - $\mathrm{i}$ to $\mathrm{z}$ wielu powodów, o których będzie mowa poniżej. Z góry można jednak powiedzieć, że najpewniej dlatego, iż nie jest on w nią bezpośrednio zaangażowany i, co więcej, stoi niejako po dwóch stronach omawianego sporu: jest konserwatywny w swoich arystotelesowsko-tomistycznych zapatrywaniach i zarazem nowoczesny w podejściu krytycznym, łączącym elementy kantyzmu i marksizmu, a wraz z nimi i przekonanie, że jedynym miejscem dla racjonalnej dyskusji jest sfera publiczna.

\section{Uchodźcy a sprawa niemiecka}

Pod fotografią z udręczonymi tułaczką uchodźcami na granicy między Grecją a Macedonią redaktorzy „Die Zeit” w grudniu 2015 roku zamieszczają odpowiedzi na pytanie, które wcześniej zadali filozofom i filozofkom z „całego świata”, o to, „co pozostało po Kancie?” - filozofia Kanta ma być wyraźnie kluczem do intelektualnego i politycznego poradzenia sobie z problemami współczesnego świata. Jakie są to problemy - i dlaczego akurat Kant?

Najpierw krótki serwis informacyjny. Temat, który najbardziej emocjonuje dziś Europejczyków, domaga się podejmowania szybkich i odważnych decyzji politycznych na forach instytucji unijnych oraz parlamentów i rządów poszczególnych państw, w sprawie zakrojonych na szeroką skalę działań logistycznych związanych z udzielaniem pomocy uchodźcom z objętych wojnami domowymi terenów Syrii, Libii i Iraku. Dołączają do nich masowo imigranci ekonomiczni z Afganistanu, Somalii i innych ubogich krajów. Szacuje się, że przed bramami Europy czeka dziś około 6o-milionowa rzesza potencjalnych uchodźców, głównie z obszaru Afryki. Tak wielkich migracji ludności nie było od czasów II wojny światowej. Docelowo wszyscy szukają schronienia w zamożnych krajach europejskich, głównie w Niemczech, Austrii, Szwecji czy Norwegii. Wszędzie tam też toczy się debata publiczna - przybysze budzą namiętne dyskusje: idzie o związany z nimi rachunek ekonomiczny, ale nie tylko, także kulturowy. Państwa demokratyczne stoją przed problemem integracji ludzi ze społeczeństw tradycyjnych, z właściwymi im nierównościami, przede

1 Zob. Was bleibt von Immanuel Kant? Philosophinnen und Philosophen aus aller Welt erklären, was der deutsche Denker uns heute bedeutet, "Zeit Online” 17. Dezember 2015 Nr. 49. Zob. też Wir dürfen Kant nicht missverstehen, z filozofem Rainerem Forstem rozmawia Thomas Assheuer (tamże). 
wszystkim z upośledzeniem społecznym kobiet. A ono wiąże się z religią. Zsekularyzowana w dużym stopniu Europa, nadal w wielu swych częściach pozostająca jednak, przynajmniej kulturowo, chrześcijańska - większość rządzących w niej obecnie partii politycznych deklaruje się jako chadeckie przyjmuje muzułmanów, musi zmierzyć się zatem z islamem, który nie tylko budzi sprzeciw jej mieszkańców wobec zjawiska nierówności płci, lecz także, przede wszystkim, przeraża ich fanatyzmem i terroryzmem. Terroryści islamscy zabijają przypadkowych sto kilkadziesiąt osób w Paryżu w listopadzie 2015 roku (w marcu 2016 roku, kiedy piszę te słowa, dochodzi do zamachów bombowych w Brukseli, ginie tam kilkadziesiąt osób na lotnisku i w metrze), dokładnie w tym samym czasie, kiedy regularnie, codziennie tysiące muzułmańskich uchodźców prosi o pomoc i schronienie rządy Francji, Wielkiej Brytanii, Niemiec... Wielu spośród imigrantów zostało wygnanych ze swoich domów przez tych samych najpewniej terrorystów i ich mocodawców, co nie zmienia faktu, że tzw. przeciętny obywatel gościnnych państw, przerażony aktami terroru, staje się naturalnie podatny na oddziaływanie polityki strachu i podziałów, narzucającej kojarzenie napływu ofiar z inwazją katów. Ale obywatel ten staje też i przed pytaniem moralnym, czy sprawiedliwość wymaga, aby popierał przyjmowanie obcych w potrzebie, czy też był przeciw nim?

Pytanie to brzmi szczególnie doniośle w Niemczech, które w 2015 roku zarejestrowały u siebie ponad milion uchodźców. W Niemczech, których powojenna tożsamość narodowa była niemal nieustannie budowana na doświadczeniu opuszczenia własnego kraju i ucieczki, włączając w to ponowne zjednoczenie w 1990 roku oraz następującą po tym wydarzeniu, w latach 90., ostatnią wielką falę imigrantów, tzw. późnych przesiedleńców, z Europy Środkowej i Wschodniej, głównie z krajów byłego ZSRR. Ale otwartość na uchodźców wyróżnia Niemcy z jeszcze jednego powodu. Otóż to oni właśnie w nowoczesnej Europie najbardziej ujęli się za uchodźcami na gruncie filozofii czy też tego, co dziś nazwalibyśmy nauką o polityce. Jak wiadomo, uczynił to Immanuel Kant w swojej rozprawie z 1795 roku zatytułowanej Do wiecznego pokoju. Projekt filozoficzny, gdzie temat uchodźców został połączony z tytułową ideą wiecznego pokoju, skądinąd znaną od początku XVIII wieku, i potraktowaną jako najwyższe dobro polityczne. Żeby państwa, zorganizowane na zasadach republikańskich, mogły połączyć się w jeden federalny związek wolnych państw, jak tego chce rozum, w praktyce muszą podlegać prawu kosmopolitycznemu, czyli „ogólnoświatowemu prawu obywatelskiemu”, które „powinno być ograniczone do warunków powszechnej gościnności”. Gościnność (Hospitalität), jak dalej tłumaczy Kant, „oznacza prawo obcego 
przybysza, ażeby z powodu, iż przebywa na terytorium należącym do kogoś innego, nie był przez tego kogoś traktowany wrogo". Prawo to bynajmniej nie ma wynikać z jakiejś dobroczynności domowników, uzależnionej od ich zmiennych nastrojów i emocji, lecz z naturalnego stanu rzeczy, a mianowicie z „prawa do wspólnego posiadania powierzchni Ziemi”2, która przecież jest własnością nas wszystkich, niezależnie od miejsca urodzenia i zamieszkania.

Filozofia polityczna Kanta jest implikacją jego dramatycznego pytania o człowieka, pytania złożonego z części teoretycznej - „co mogę wiedzieć?”praktycznej - „co powinienem czynić?” - oraz praktyczno-teoretycznej, zwróconej ku wyobraźni - „czego mogę się spodziewać?”3. To wszystko rozterki i dylematy podmiotu nowoczesnego, żyjącego w niepewności, wykorzenionego, wrzuconego w świat, jak chętnie będą go opisywali XX-wieczni potomkowie Kanta, i zarazem uzależnionego też od tego świata, skazanego na swoich bliskich i dalekich bliźnich. Uruchomiona przez to pytanie refleksja przenika do myśli niemieckiej następnych wieków, próbującej przełamać indywidualizm nowożytnej filozofii zachodniej, dowodząc, że bezdomność nie jest ani kosmicznym, ani społecznym przeznaczeniem człowieka. Istota ludzkiego istnienia nie może być więc zawarta w samotnym indywiduum, lecz we współistnieniu z drugim człowiekiem.

Intuicja ta jeszcze przed II wojną światową zostanie rozpracowana przez filozofów dialogu, takich jak Franz Rosenzweig czy Martin Buber, łączących myśl zachodnią z tradycją żydowską, wrogą nowoczesnemu indywidualizmowi, powiązanemu z bezdomnością społeczną i kosmiczną ludzkiej osoby. Odrzucenie wizji jednostki osamotnionej w świecie, którego nie odczuwa jako dom, jest także udziałem fenomenologów, takich jak Max Scheller, który analizuje formy sympatii - „współ-czującego serca” lub „spontanicznej powszechnej miłości do człowieka" - w kontekście i w opozycji do racjonalistycznej kultury Zachodu. Nie sposób nie wspomnieć w tym fleszu historycznym także i o Hannah Arendt, zmuszonej do bronienia przed Europą i całym światem godności wypędzonych z własnego kraju Żydów jako istot ludzkich. Filozofka obnaża w ten sposób fałszywość wielkiej zachodniej tradycji intelektualnej, która poniosła totalną klęskę w zderzeniu z nacjonalizmem

2 Trzy cytaty: I. Kant Do wiecznego pokoju. Projekt filozoficzny, przeł. M. Żelazny, w: I. Kant O porzekadle: To może być słuszne w teorii, ale nic nie jest warte w praktyce. Do wiecznego pokoju. Projekt filozoficzny, COMER, Toruń 1995, s. 65.

3 I. Kant Krytyka czystego rozumu, t. 2, przeł. R. Ingarden, PWN, Warszawa 1986, s. 548 (A805, B 833). 
i nazizmem. „Wspólnota narodów Europy - jak kończy w 1943 roku swój artykuł pod tytułem My, uchodźcy - upadła wtedy, gdy pozwoliła, by był wyklęty jej najsłabszy członek; upadła dlatego, że na to pozwoliła"4.

Dzisiaj wydarzyła się rzecz niezwykła: uchodźcy w oczach średniego pokolenia lewicowych intelektualistów niemieckich wyznaczają punkt zwrotny w powojennych dziejach ich kraju, mają potwierdzać ostateczne jego rozstanie się z tragiczną przeszłością i powrót do zapoznanych idei gościnności i współodczuwania. Harald Welzer, socjolog i publicysta z Europa-Universität we Flensburgu, entuzjastycznie pisze w „Der Spiegel” we wrześniu 2015 roku:

I teraz, wraz z tą wielką ucieczką, dzieje się coś całkiem nie do uwierzenia, co zostanie przeoczone w oślepiającym świetle oburzenia podpaleniami [domów dla uchodźców - J.P.H.] przez neonazistowskich terrorystów oraz nieświadomą lub otwarcie rasistowską postawą wobec uchodźców w innych krajach europejskich: Niemcy dla ludzi z całego świata stały się krajem, za którym się tęskni [Sehnsuchtsland], krajem, na którym skupia się nadzieja na to, że może i da się jeszcze żyć w prawie, wolności i bezpieczeństwie. Sadzę, że jest to największy komplement wobec tego kraju, jeśli ludzie piszą sobie na rękach wyciągniętych ku kamerom "Germany” $\mathrm{i}$ jeśli w najrozmaitszych grupach uchodźców oraz chętnych do emigracji mówiło się, że to właśnie jest ten kraj, w którym warto żyć i pracować.

Takim upragnionym krajem wolności były od pierwszej połowy XIX wieku Stany Zjednoczone [...]. Ale paradoksalnie właśnie ten kraj, z którego wyszła największa masowa zbrodnia XX wieku, z którego trzeba było uciekać, ponieważ było tam zagrożone życie przez rasizm i prześladowania polityczne, przejął dzisiaj nimb wolności i państwa prawa, którego USA już nie posiadają. ${ }^{5}$

Niemcy po raz pierwszy od zakończenia II wojny światowej, dzięki uchodźcom, czują się wolni od balastu własnej przeszłości, od konieczności identyfikowania się z państwem, które nosi na sobie historyczną winę, przepracowywaną jeszcze do niedawna w debatach publicznych związanych z tzw. sporem historyków (rozpoczętym w 1986 roku przez Jürgena Habermasa) czy

4 H. Arendt My, uchodźcy, przeł. H. Bortnowska, w: Pisma żydowskie, przeł. M. Godyń i in., Biblioteka Kwartalnika Kronos, Warszawa 2012, s. 310.

5 H. Welzer Deutschland, ein Sehnsuchtsland, „Der Spiegel” 2015 Nr. 38. 
też z głośną mową Martina Walsera, z okazji przyznania mu nagrody pokojowej w 1998 roku, poświęconą pamięci Holokaustu6 .

\section{Kant i publiczny użytek filozofii}

Pytanie o Kanta w XXI wieku w debacie publicznej toczącej się wokół najpoważniejszych dla współczesności problemów politycznych i społecznych - kryzys tożsamości narodowej i kryzys migracyjny - to także pytanie o filozofię w ogóle i o jej użyteczność dla praktyki: czy jest ona w stanie ingerować $\mathrm{w}$ funkcjonowanie instytucji państwa i społeczeństwa?

Pytanie to samo w sobie jest problematyczne, i to przynajmniej z dwóch powodów. Po pierwsze dlatego, że kierowane jest do uczonych zatrudnionych zwykle na uniwersytetach państwowych, którzy z zasady są/powinni być lojalni wobec swojego pracodawcy, czyli państwa. Jakże więc mogą go krytykować? Ale jest też i drugi powód, dla którego tak postawione pytanie budzi wątpliwości - tym razem natury, nazwijmy to, metodologicznej. Otóż z perspektywy filozofii klasycznej jest ono aktem rezygnacji z lub wręcz zdrady wobec idei poznania teoretycznego - theoros oddaje się bowiem kontemplacji, poznaniu dla samego poznania, $\mathrm{i}$ to czyni go bogom podobnym. Historycznie patrząc, zarzut praktycznego zastosowania rozważań filozoficznych staje się bezzasadny od czasu tzw. zwrotu nominalistycznego w myśli zachodniej, którego sens polegał na zrównywaniu teorii z praktyką i postrzeganiu przez nią przedmiotów swoich dociekań jako swoich własnych konstrukcji.

Chociaż Platon i Arystoteles zakładali szkoły i w nich, wśród przyjaciót, uprawiali filozofię, to jednak teorię, jako rodzaj „,wiedzy i poznania dla nich samych"', a nie dla jakichkolwiek innych korzyści, uważali za przygodę samotnika. Żywa mowa, która dla Platona miała być nośnikiem prawdy bytu, pismo zaś tylko jego słabym, pospolitym odbiciem/kopią, w rzeczy samej - co potwierdzają Platońskie dialogi - była jedynie pozorowana, dialog był bardziej chwytem retorycznym i dydaktycznym niż autentyczną metodą dochodzenia do prawdy. Filozof klasyczny pierwotnie więc monologuje, w teoretycznej kontemplacji relacje międzyludzkie nie tylko mają mu

6 Zob. wszystkie najważniejsze teksty dla powojennego dyskursu tożsamościowego Niemiec w antologii: O kondycji Niemiec. Tożsamość niemiecka w debatach intelektualistów po 1945 roku, wyb. i oprac. J. Jabłkowska, L. Żyliński, Wydawnictwo Poznańskie, Poznań 2008.

7 Arystoteles Metafizyka, przeł. K. Leśniak, PWN, Warszawa 1983, s. 8 (982 a). 
"przeszkadzać”, lecz wręcz go „ośmieszać”, dlatego pojawia się on na agorze jedynie po to, żeby zaprezentować to, co wcześniej, w samotności udało mu się przeniknąć własnym rozumem. Inaczej filozof nowoczesny. Kiedy Kant udziela odpowiedzi na pytanie, „co to jest Oświecenie?”, to właściwie zgadza się z klasykami, dochodząc do wniosku, że idzie tu o coś źródłowo filozoficznego, o nasze kierowanie się rozumem, myśleniem wolnym, na własny rachunek, ale - i tu różnica - uważa, że nie można tego myślenia praktykować kosztem zerwania relacji międzyludzkich, że nie jest to akt samotnej kontemplacji. Rozumujemy bowiem zawsze w towarzystwie innych osób, i to szczególnych, tych mianowicie, z którymi w danym miejscu i czasie podzielamy pewne wspólne przekonania. Nasze dociekania i debaty przebiegają zawsze w pewnym specyficznym społecznym i intelektualnym kontekście. Publiczność, do której zwracał się Kant w Berlinische Monatsschrift była siecią subskrybentów i korespondentów tego periodyku oraz członków związanego z nim Towarzystwa Przyjaciół Oświecenia (Gesellschaft der Freunde der Aufklärung). Filozof włącza się do wspólnej konwersacji, występując „wobec całej publiczności czytającego świata”, czyni - jak powiada - „publiczny użytek” ze swego rozumu?.

Dla Kanta nowożytne zrównanie teorii z praktyką otwiera przed filozofią możliwość organizowania społeczności w pewną „sztuczną jedność"10 skierowaną ku celom publicznym. Wiąże się więc ono ze świadomością konstrukcyjności świata społecznego i odpowiedzialności filozofa za jego kształty. Najpewniej ten właśnie wątek odpowiedzialności mają na względzie redaktorzy „Die Zeit”, pytając dziś filozofów o Kanta.

\section{Wojna domowa: „esteci" $i$,terapeuci" przeciw barbarzyńcom}

Niemiecka debata intelektualistów na temat uchodźców w swych najważniejszych momentach ilustruje Kantowskie przekonanie o tym, że obcowanie z innymi ludźmi jest kwestią praw uniwersalnych, dla wszystkich

8 Zob. Arystoteles Etyka nikomachejska, przeł. D. Gromska, PWN, Warszawa 1982, s. 384 (1178 b), s. $379-380$ (1177a-1177 b).

9 I. Kant Co to jest Oświecenie?, przeł. A. Landman, w: Przypuszczalny poczatek historii i inne pisma historiozoficzne, przeł. M. Żelazny i in., COMER, Toruń 1995, s. 55. Zob. Na ten temat: A. Maclntyre Some Enlightenment Projects Reconsidered, w: Ethics and Politics. Selected Essays, Vol. 2, Cambridge University Press, Cambridge 2006, s. 174-175.

10 I. Kant Co to jest Oświecenie?, s. 55. 
zrozumiałych. Innego człowieka można obiektywnie poznać, a relacje z nim są możliwe do opisania za pomocą dychotomii uniwersalny/partykularny, kulturalny/niekulturalny... Instytucjonalne forum, na którym toczy się ta debata, to prasa, ogólnie: media w przeważającej mierze liberalne, co z góry zdaje się przesądzać jej wyniki. Filozofowie, jak wszyscy inni, ulegają pokusom poprawności politycznej.

Punktem zapalnym dyskusji publicznej jest krytyka polityki migracyjnej rządu kanclerz Angeli Merkel, w szczytowym okresie masowego napływu uchodźców, tj. w drugiej połowie 2015 i na początku 2016 roku, przez najważniejszych niemieckich intelektualistów: Petera Sloterdijka, Rüdigera Safranskiego, Botho Straußa i innych. Prasa nie szczędzi im epitetów: nazywa „falangą"1 (skojarzenie z faszystami), twórcami „nowej konserwatywnej rewolucji”, „wymuskanymi myślicielami na manowcach”12, „bezmyślnymi mędrcami”, „tymczasowymi mentorami Republiki” (to à propos Sloterdijka i Safranskiego) ${ }^{\mathbf{1 3}}$.

Przeciw polityce otwartych granic wypowiada się Sloterdijk w rozmowie $\mathrm{z}$ redakcją czasopisma „Cicero”, pod znamiennym tytułem Nie ma moralnego obowiązku samozniszczenia ${ }^{14}$. Wywiad wywołuje falę komentarzy - ich wspólnym mianownikiem jest tropienie prawicowych, nacjonalistycznych poglądów rozmówcy. Zdanie z tej rozmowy - „teraz to uchodźca decyduje o stanie wyjątkowym" - w komentarzu Armina Nassehiego, profesora socjologii, jednego z najważniejszych dziś publicznych intelektualistów w Niemczech, ma wyraźnie konotacje z myślą Carla Schmitta (teoretyka ideologicznych podstaw dyktatury nazistowskiej - samo posłużenie się tym nazwiskiem w niemieckiej debacie publicznej stanowi już zniesławienie) i znaczy tyle, że sam uchodźca jest suwerenem. Nie jest to tylko niewinna gra słów, lecz twierdzenie wprost, że prawdziwy suweren dawno utracił już swoją suwerenność przez politykę otwartych granic - zapewnia Nassehi na łamach „Die Zeit”15. Socjolog twierdzi dalej, że Sloterdijk opisuje uchodźców jak jakieś ciało obce,

\footnotetext{
Zob. Ch. Schröder Botho Strauß, Rüdiger Safranski, Peter Sloterdijk. Deutsche Denker gegen Angela Merkel, „Tagesspiegel” 01.02.2016.

H. Hütt Die Heimatvertriebenen, „Die Zeit” 3. Februar 2016. H. Münkler Wie ahnungslos kluge Leute doch sein können, "Die Zeit", 20. Februar 2016, Nr. 7.

Zob. P. Sloterdijk, "Es gibt keine moralische Pflicht zur Selbstzerstörung”, "Cicero. Magazin für Politische Kultur", 28. Januar 2016.

A. Nassehi Jenseits der Reflexe , "Zeit Online”, 11. März 2016.
} 
które wnika w i tak już kruchy twór tego, co własne, i stanowi wyzwanie dla zdolności obronnych jego tożsamości. Konkluzje: ignorant w zakresie socjologii, filozoficzny erudyta głosi ideologię nacjonalistyczną, chociaż nigdzie wprost nie posługuje się prawicowymi resentymentami, to jednak wszystkie jego argumenty zbudowane są na wyobrażeniu pewnego kolektywnego podmiotu zagrożonego przez uchodźców ${ }^{16}$. Inni polemiści potwierdzają tę opinię. W użytym przez filozofa w omawianym wywiadzie wyrażeniu „imperatyw terytorialny" słyszą hasło nacjonalistyczne, antyeuropejskie, zaprzeczenie „imperatywu humanitarnego", co ma dodatkowo potwierdzać jego zdanie: „Państwu narodowemu można prorokować długie życie, ponieważ jest ono jedynym wielkim tworem politycznym, który aktualnie jako tako funkcjonuje"17. Według redaktora „Frankfurter Allgemeine Zeitung” (FAZ), tym razem gazety o profilu konserwatywnym, autor tych słów nie rozumie, że omawiany problem może być rozwiązany tylko w kontekście europejskim, a nie narodowym, że myśli i mówi on „prawicowo”, „,nieludzko i antyeuropejsko”, co czyni jego udział w debacie „no-go-area dla ludzi kulturalnych”18.

Prezentowana tu dyskusja opiera się na ogólnym założeniu, że myślenie krytyczne polega na operowaniu binarnymi opozycjami między uniwersalnym (czyli liberalnym, lewicowym) a partykularnym (to jest konserwatywnym, prawicowym), lub - w innych wariantach - między jednostką a wspólnotą, wolnością a zniewoleniem, prawami człowieka i obywatela a ideologią Blut und Boden (Krwi i Ziemi) ${ }^{19}$. Intelektualiści, a w szczególności filozofowie, jak brzmi jedna z przepisanych im w prasie recept, powinni wybierać te pierwsze człony dychotomii, ponieważ uczyni ich to „ekspertami” w tym, jak postępować ze złożonymi, wewnętrznie sprzecznymi strukturami społecznymi, a nie kultywować „myślenie tożsamościowe”, wyrażające „ducha panowania"20.

Owszem, pojawiają się też i inne głosy, wedle których to myślenie tożsamościowe, odwołujące się do uczuć strachu przed obcymi, nie musi być

\footnotetext{
16 Tamże.

17 Cyt. za: Ch. Geyer Migration als Reflexzonenmassage, "Frankfurter Allgemeine Zeitung”, 31.01.2016.

18 Tamże.

19 O tej ostatniej dychotomii pisze: D. Hornuff Intellektuelle, traut euch was!, „Deutschlandradio Kultur", Montag, 11 April 2016.

20 Tamże.
} 
od razu antydemokratyczne. Demokracji nie można bowiem zredukować do liberalnego racjonalizmu, do domeny trzeźwej wymiany argumentów, ponieważ ukrywa się przez to jej wymiar emocjonalny, agonistyczny. Diagnoza wygląda tak: jeśli otwarta na świat demokracja nie potrafi uwzględniać emocji i namiętności, przez specyficzne formy kanalizowania uczynić je częścią polityki postępowej, to oddaje je do dyspozycji szaleńcom, tym, którzy wykorzystają je do budzenia nienawiści i przesądów, tak jak to czyni dziś w Niemczech PEGIDA (Patriotische Europäer gegen die Islamisierung des Abendlandes). Być społeczeństwem oznacza zarządzać niepokojem we wspólnej przestrzeni komunikacyjnej, czynić troski, lęki i oburzenia wspólnym doświadczeniem. Demokracja polega dziś na publicznym, medialnym negocjowaniu tego, które troski, potrzeby i lęki mają wagę społeczną. Uczucia te w aktualnej debacie na temat azylu domagają się właściwego rozpoznania - u którego z „zatroskanych obywateli” strach jest manifestacją nienawiści, a u którego jedynie objawem faktycznego lęku przed degradacją - i demokratycznego skanalizowania. Takie jest zalecenie Nilsa Markwardta ${ }^{21}$.

MacIntyre skomentowałby powyższe opnie zapewne tak: liberalni krytycy zachowują się jak „terapeuci” lub „esteci”, główne postaci (oprócz „menedżerów") dramatu nowoczesności, ofiary fikcji moralnych ${ }^{22}$, odwołujące się do porządku politycznego, narzucającego społeczeństwu jedność za pomocą uniwersalnych praw. Taki porządek - dalej hipotetycznie według szkockiego filozofa - zaciemnia naturę politycznego zobowiązania, wyrażaną w patriotyzmie. A jest to uczucie/zobowiązanie bynajmniej niełatwe - idzie przecież, używając znanej frazy, o jedność w różnorodności, o to, że nasze patriotyczne zadanie polega na podtrzymywaniu możliwości wspólnego życia przy zachowaniu tego wszystkiego, co różni nas jako jednostki i grupy. Uniwersalne prawa społeczne czy polityczne nigdy nie dopasują do siebie wszystkich tych naszych potrzeb, interesów, krótko: roszczeń do różnienia się - zawsze będziemy więc żyli z niepokojami i sporami społecznymi. To jasne. „Natury żadnego społeczeństwa - napisze we właściwej sobie esencjalistycznej stylistyce autor Dziedzictwa cnoty - nie da się odczytać z samych jego praw, lecz z praw pojmowanych jako wskaźnik jego konfliktów"23. Terapeuci i esteci (teraz to tyle, co poprawni politycznie) próbują jedynie te konflikty tłumić

21

22

\footnotetext{
N. Markwardt Willkommen in Panikland, „Die Zeit” 28 Januar 2016.

Zob. A. Maclntyre Dziedzictwo cnoty. Studium z teorii moralności, przeł. A. Chmielewski, PWN, Warszawa 1996, s. 146-147.

Tamże, s. 451.
} 
- bezskutecznie. Owszem, mają oni rację, że w dzisiejszym świecie patriotyzm jest często „fasadą, za którą kryje się szowinizm i imperializm" ${ }^{24}$, ale ich demaskatorskie podejście nie uwzględnia własnych uwarunkowań, tzn. nie ujawnia opresji kryjącej się za moralną maską sprawujących władzę w państwie. A państwo to jest instytucją konfliktogenną, narzucającą na społeczeństwo „zbiurokratyzowaną jedność”, która nie ma nic wspólnego z „moralną zgodą", uwikłana jest zawsze w doraźny/przypadkowy układ relacji władzy i kapitału. Uwarunkowania ich, owych terapeutów i estetów, krytycznego/ liberalnego myślenia są związane z legitymizacją tej władzy - obiektem ich krytyki są krytycy władzy państwowej, a nie ona sama.

Polityka wspierana przez lojalnych krytycznych intelektualistów nie opiera się na ,autentycznej zgodzie moralnej” - mamy tu raczej do czynienia z „wojną domową" 25 prowadzoną za pomocą aksjologii liberalnej, która poza retoryką pluralizmu ideałów społecznych i programów politycznych, ukrywa rzeczywiste konflikty społeczne. W rezultacie spory, jakie toczą się dziś w niemieckiej sferze publicznej, pozostają nierozstrzygalne „w racjonalny sposób” zarówno na płaszczyźnie filozoficznej, jak moralnej i politycznej. A to by także znaczyło, że uwzględnienie momentu „zgody moralnej” związanej z lojalnością wobec tego, co lokalne i partykularne, nie oznacza odrzucenia tego, co uniwersalne, że takie dualistyczne myślenie (uniwersalne/partykularne, liberalne/konserwatywne) jest nieuprawnione. Dyskurs patriotyczny nie musi być więc dyskursem barbarzyńców. Twierdzenie to zakłada, że nie da się odróżnić "przedmiotu" narracji lub opisów zachowań i postaw patriotycznych, od samych tych narracji i opisów. Nie ma czystego/prawdziwego patrioty oczyszczonego z języka na jego temat - tak samo jak czystego/prawdziwego barbarzyńcy. Szkocki filozof nie ma wątpliwości co do tego, że rządy prawa trzeba zachować, niesprawiedliwości i nieuzasadnione cierpienia zwalczać, ale twierdzi przy tym, że „każde określone zadanie jednak, każda rzecz, którą należy wykonać, musi być oceniana sama w sobie, na podstawie jej własnych zalet"26. Ale to znaczy ni mniej, ni więcej tyle, że każda rzecz domaga się swojego własnego opisu, języka, opowiadania. Na taki zabieg nie ma jednak miejsca - jak można wnosić z przedstawionej relacji - w niemieckim dyskursie migracyjnym. Zdominowany jest on dziś przez media liberalne, których

24 Tamże.

Tamże, s. 450 . 
ideowe ramy reprezentuje filozofia dualistyczna, operująca dychotomiami obiektywny/subiektywny, prawdziwy/fałszywy. Opozycje te w odniesieniu do myśli społecznej wyrażają się w podziałach na liberalny/konserwatywny, lewicowy/prawicowy, ale także: przyjacielski/wrogi. Jest to myślenie z gruntu monologiczne, z którym nie daje się racjonalnie dyskutować, jeśli zgodzić się na MacIntyre'owskie kryteria racjonalnej dyskusji.

\section{Kant i problem izolacji teorii od praktyki}

Jedna z prób wyjaśniania przyczyn zarzucanego akademikom błądzenia w debacie o uchodźcach wskazuje na hermetyczność filozofii politycznej ${ }^{27}$.Zarzut zdaje się odnosić do zjawiska sprofesjonalizowania teorii, na które skądinąd narzeka także MacIntyre, widząc w nim zresztą jeden z powodów jej bezsilności politycznej. Profesjonalizacja procedur, podział aktywności według pełnionych ról zawodowych i społecznych czy wreszcie ewaluacja efektów tych działań w kategoriach zysków i strat miałyby być trzema głównymi punktami oporu, jaki stawia dziś świat krytyce ze strony filozofii moralnej/ społecznej ${ }^{28}$. Ostatnio na profesjonalizację filozofii zwraca też uwagę, na łamach FAZ, Charles Taylor ${ }^{29}$. Taylora bardziej, co prawda, interesuje anglosaska filozofia analityczna, ale jego obserwacje, według redaktora FAZ, zdają się stosować także do filozofii niemieckiej. Chodzi o to, żeby filozofia przestała być zawodem, wyszła z akademickiej wieży z kości słoniowej i zwróciła się ku praktyce, ku warunkom realizacji swoich idei, co, jak sugeruje Taylor, mogłaby osiągnąć przez przełamywanie granic dyscyplinarnych między filozofią, historią i polityką. Taylora niepokoi to, że:

W sukcesji po Johnie Rawlsie powstał pewien kierunek filozofii politycznej, który zasadniczo lekceważy politykę. Chodzi mu wyłącznie o to, co normatywne. Jeśli mówię, że lekceważy on politykę, to rozumiem przez to, że nigdy nie dociera on do warunków swojego własnego urzeczywistnienia. ${ }^{30}$

Ch. Geyer Migration als Reflexzonenmassage.

A. MacIntyre Moral Philosophy and Contemporary Social Practice: What Holds Them Apart?, w: The Tasks of Philosophy. Selected Essays, Vol. 1, Cambridge University Press, Cambridge 2006, S. 114, 121-122.

Zob. tamże. 
I faktycznie tak scharakteryzowany kierunek zdaje się dominować w publicznym dyskutowaniu filozofów o uchodźcach. To właśnie podejścia normatywne izolują teorię od praktyki, zamieniają ją w dyskurs moralizatorski uwikłany w konteksty polityczne. Zwykle wykorzystują one do tego celu Kanta. Argumentacja jest prosta, wygląda przykładowo tak (przekonuje na łamach prasy jeden z filozofów, kantysta): „Musimy wraz z Kantem trzymać się ideału społeczeństwa republikańskiego, ponieważ tylko w nim ludzie mają udział w sprawowaniu władzy”. I dalej: „Polityka kanclerz Merkel jest o tyle zgodna z duchem kantowskim, o ile poważnie traktuje prawo do azylu jako roszczenie prawne [Rechtsanschpruch]. Sama wspaniałomyślność [Großherzigkeit] tu nie wystarczy. Wspaniałomyślność jest wprawdzie według Kanta godna pochwały, rzecz w tym jednak, że może być ona pewną formą samowoli. Dlatego właśnie polityka wobec uchodźców musi być polityką prawa i sprawiedliwości” - konkluduje w „Die Zeit” Rainer Forst ${ }^{31}$. W „Der Spiegel” inny filozof w tym samym duchu przestrzega: „Przybywajaccy do nas nie powinni być postrzegani jako środek do celu, ani demograficznego czy ekonomicznego, ani [jako środek do naszej - J.P.H.] samorealizacji. Z kantowskiej perspektywy uchodźca jest najpierw celem samym w sobie. Nie chodzi o to, co ludzie mogą dla nas zrobić, lecz o to, jak możemy im pomóc. Ponieważ większość z nich pierwotnie potrzebuje jednego: ochrony przed konkretnym prześladowaniem i zagrażającym życiu niebezpieczeństwem. Na tym polega też rzeczywiście istota prawa azylowego"32.

We współczesnej kulturze zachodniej dla pokojowego współistnienia ludzi kluczowe znaczenie mają państwo prawa i prawa człowieka, jedno i drugie należy chronić. To nie ulega wątpliwości. Otwarte pozostaje jednak pytanie, czy takie humanitarne myśli nie są aż nadto abstrakcyjne w zestawieniu z rzeczywistością, zawikłaną i niejednoznaczną, że przeoczają wiele praktycznych uwarunkowań ich aktualizacji? Czy - pytając po MacIntyre'owsku - filozofia polityczna musi być tylko składnikiem „kultury biurokratycznego indywidualizmu", która uwidacznia się w typowych dla nowoczesnych społeczeństw debatach politycznych „pomiędzy indywidualizmem, formułującym swoje tezy w języku praw, a organizacjami biurokratycznymi, które formułują swoje dezyderaty w kategoriach użyteczności"33? Czy każda inna filozofia musiałaby

31

32

Wir dürfen Kant nicht missverstehen...

Philosophen über Flüchtlingskrise: Das Ende der Lebenslüge, z Wolframem Eilenbergerem rozmawia Annette Langer, „Der Spiegel” 11 Januar 2016.

A. Maclntyre Dziedzictwo cnoty..., s. 143. 
w tych warunkach być od razu rzeczniczką ideologii Blut und Boden? Trzeba by wreszcie też zapytać, jak się ma owa filozofia „kultury biurokratycznego indywidualizmu" do niemieckiego świata życia?

\section{"Myśleć lewicowo, żyć prawicowo"}

Zacznę od pytania ostatniego. Jedną z możliwych, wspartą na badaniach empirycznych, odpowiedzi na nie udziela w ramach omawianej debaty wywołany tu już Armin Nassehi. Twierdzi on, że do niemieckiego społeczeństwa nie stosują się już stare kategorie polityczne typu lewica - prawica. „To, że coś jest prawicowe czy lewicowe - pisze - konserwatywne czy postępowe, zawiera coraz mniej wartości informacyjnych". Świat społeczny staje się bowiem coraz bardziej złożony, faktyczne linie podziałów coraz bardziej nieprzejrzyste. Mijanie się teorii z praktyką w Niemczech opisuje on krótko w jednym zdaniu: „myśleć lewicowo, żyć prawicowo"34. Jest to obserwacja skądinąd dobrze znana MacIntyre'owi. O większości z nas współczesnych mówi on jako o osobowościach wyalienowanych, oderwanych od spójnych zbiorów dyspozycji, uczuć, myśli i „języka-w-użyciu”, w codziennym życiu akceptujących „bezrefleksyjnie założenia dominujących, liberalnych, indywidualistycznych form życia publicznego, ale równocześnie w różnych sferach swojego życia czerpią [cych] z wielu dostarczonych przez tradycję form myśli i działania, które są przekazywane przez rozmaite rodzinne, religijne, wychowawcze oraz inne społeczne i kulturowe źródła" ${ }^{\prime 35}$.

Nie sposób w tych warunkach rozstrzygać konflikty za pomocą racjonalnej argumentacji. W swej najnowszej książce Die letzte Stunde der Wahrheit w związku z eskalacją wrogości i resentymentu - szczególnie w Saksonii wobec obcych przybywających do kraju i zagrażających mu jakoby islamizacją oraz obciążeniami dla państwa socjalnego - Nassehi twierdzi, że nie da się tego strachu - mętnych uczuć obcości, nieprzejrzystości i niepewności, wyprowadzających tysiące ludzi na ulice miast - rozwiać przez uniwersalistyczną argumentację. Nie da się uczynić świata bardziej przejrzystym przez podawanie ludziom twardych informacji o tym chociażby, że ci przybysze są jednoznacznie płatnikami netto do kasy socjalnej. Okazuje się, że lewicowe, a więc uniwersalistyczne argumentowanie przeciw tego rodzaju lękom

Zob. V. Weiß Neue Rechte: Ab wann ist konservativ zu rechts? „Die Zeit” 19 Februar 2016. 
społecznym, obojętnie, czy są one rzeczywiste, czy urojone, jest przeciwskuteczne. Wniosek Nassehiego:

Mowa lewicowa, ta, która postrzega społeczeństwo jako projekt, jest jedyną, która jako myślenie, daje się sprawdzić, jest jakoś akceptowalna, jednak przeżywana może być ona jedynie z wielkim trudem. Lewicowe, uniwersalistyczne myślenie potrzebuje już tego nowego człowieka, którego chce dopiero stworzyć. Nie ma takiej możliwości, żeby wyrazić niepokój nieprzejrzystego świata - nawet w sentymentalnej formie, dalekiej od habitusu tych, którzy zarabiają pieniądze na opisywaniu świata. ${ }^{36}$

Filozofia, która narzuca transcendentalne ramy, w postaci idei wolności i praw człowieka, na publiczną debatę o uchodźcach, pozostaje głucha na doświadczenie różnorodności form życia społecznego, kruchych, niestabilnych, miotanych dziedziczonymi i nowo nabytymi potrzebami, emocjami i niepokojami. Abstrakcyjne ujęcia, którymi operuje filozofia, względnie teoria społeczna w ogóle, nie trafiają w ten nieprzejrzysty, wieloraki świat przeżywany „zwykłych ludzi” - ujęcia te nie są jednak tylko niewinnymi spekulacjami czy dziwactwami. Mają one moc sprawczą, performatywną, wzmacniają bowiem, jakby to ujął MacIntyre, świat fikcji, „theatrum ułudy”, na którym ma opierać się większość naszych wypowiedzi i praktyk moralnych ${ }^{37}$. Fikcja ta to nowoczesne złudzenie, „że istnieje gdzieś dostępne nam źródło władzy, za pomocą której wszelkie formy zła tego świata można usunąć"38. Urokom takiej wizji według Szkota może oprzeć się tylko myśl krytyczna, która nie wychodzi pierwotnie z napięcia między tym, co jest, a tym, co być powinno. Raczej z rozpoznania swoich źródeł, związków ze środowiskiem społecznym, instytucjami, dyskursami bądź narracjami ${ }^{39}$. Prowadzona przez taką myśl racjonalna dyskusja musi zatem spełniać nie tylko kryteria logiczne, lecz także filologiczne (tu kwestie translatorskie) i personalne: szkocki filozof mówi dlatego o konieczności opanowania „języka-w-użyciu” oponentów

36 A. Nassehi Die letzte Stunde der Wahrheit: Warum rechts und links keine Alternativen mehr sind und Gesellschaft ganz anders beschrieben werden muss, Murmann Publishers, Hamburg 2015. Cytat z e-publikacji na stronie http://www.amazon.de/letzte-Wahrheit-AlternativenGesellschaft-beschrieben/dp/3867743770\#reader_BooU1ORQZC (1.03.2016).

Zob. A. Maclntyre Dziedzictwo cnoty..., s. 152, 153.

38

Zob. A. Maclntyre Some Enlightenment Projects Reconsidered, s. 179-180. 
oraz o pewnej empatii, pracy wyobraźni... ${ }^{40} \mathrm{Zdaje} \mathrm{się,} \mathrm{że} \mathrm{właśnie} \mathrm{tego} \mathrm{rodzaju}$ kryteria spełniał wcześniejszy, chyba najważniejszy, XX-wieczny niemiecki dyskurs o uchodźcach, w którym są oni ukazani nie tyle w świetle abstrakcyjnych norm, ile poprzez doświadczenie fenomenologicznych różnic. Opis tego doświadczenia jest dobrze znany z kultowej Dialektyki oświecenia (1947), gdzie czytamy m.in.:

Sama egzystencja innych jest drażniąca. Inni rozpierają się łokciami i trzeba ich odesłać tam, gdzie ich miejsce, wskazać granice - granice bezgranicznego strachu. Kto szuka schronienia, nie znajdzie go; tym, którzy wyrażają to, czego pragną wszyscy - pokoju, ojczyzny, wolności nomadom i kuglarzom odwiecznie odmawiano prawa osiedlania się. To, czego człowiek się boi, zostanie mu wyrządzone. ${ }^{41}$

Drażni, rozpiera się łokciami nomada, kuglarz - ktoś z krwi i kości, kto ma twarz i jest tuż obok... Autorzy tych słów domagają się sprawiedliwości dla takiego właśnie zwykłego człowieka, dla którego doświadczenia odrzucenia i bezdomności stały się ważniejsze niż abstrakcyjne prawa wolności, zadomowienia i bezpieczeństwa. Prawa te nie są fragmentem ani języka, ani świata życia wywołanych tu ludzi, w historii filozofii natomiast cieszyły się one znacznie większą uwagą niż ich (tych ludzi) odrzucenie i bezdomność.

Ten brak zainteresowania filozofii dla nomadów i kuglarzy tłumaczy skądinąd na początku lat 6o. minionego wieku Emmanuel Lévinas, reaktywując nieprzypadkowo przy okazji także kategorię sprawiedliwości. W Całości i nieskończoności (1961) pisze w związku z Heideggerem, że on „jak cała zachodnia historia, przyjmuje, że relacja z innym człowiekiem jest wpisana w los ludów osiadłych, budujących domy i posiadających ziemię"42. A takie myślenie, jako atrybut mocnego, zakorzenionego $\mathrm{w}$ domu i ziemi podmiotu, promuje instrumentalne traktowanie ludzi. Obrona abstrakcyjnej wolności i równości ludzi - tzn. sprawiedliwości statycznej, de iure, zapisanej w konstytucjach i innych aktach prawnych - niesie więc zagrożenie dla każdej ich poszczególności dla sprawiedliwości dynamicznej, de facto, o którą trzeba się stale na nowo

\footnotetext{
Zob. A. MacIntyre Czyja sprawiedliwość? Jaka racjonalność?, s. 524-525.

M. Horkheimer, Th.W. Adorno Dialektyka Oświecenia. Fragmenty filozoficzne, przeł. M. Łukasiewicz, Wydawnictwo IFiS PAN, Warszawa 1994, s. 204-205. E. Lévinas Całość i nieskończoność. Esej o zewnętrzności, przeł. M. Kowalska, PWN, Warszawa
1998, s. 36.
} 
dopominać. Życie lewicowe, odwołujące się do praw człowieka i za ich pomocą rozstrzygające problemy społeczne, nieuchronnie wyzwala więc („myślą lewicowo, żyją prawicowo") życie w strachu przed byciem innym, żeby odwołać się do głośnej formuły Theodora Adorna. Według niej sprawiedliwość to stan relacji międzyludzkich, w którym „bez lęku można się różnić”“33. Jaka jest skala lęku społecznego i objawów fobii społecznej, to już sprawa badań socjologicznych, rozpoznających grupy potencjalnie zagrożone przez politykę państwa - w omawianym przypadku politykę migracyjną. Lęku przed wykorzenieniem, wykluczeniem, zmarginalizowaniem, prześladowaniem...

\section{Dwaj Kantowie, MacIntyre i sprawiedliwość przed prawem}

Dwa wyróżnione tu rodzaje sprawiedliwości - statyczna i dynamiczna oczywiście wzajemnie się warunkują. Bez prawa stanowionego nie da się zauważyć krzywdy, która dzieje się komuś, komu to prawo nie oddaje sprawiedliwości bądź kogo ono w ogóle pomija - stąd i głosy oburzenia, żądania sprawiedliwości. Rzeczywistość $\mathrm{w}$ tym sensie zawsze więc niejako wyprzedza prawo. Sprawiedliwość, która jest przed prawem i prawdą, nie jest zasadą republikańskiej formy państwa, powiązanej z abstrakcyjną równością i wolnością.

$\mathrm{Na}$ tle takiego rozumienia sprawiedliwości trudno oprzeć się wrażeniu, że filozofia akademicka, skupiona na analizach normatywnych, w sferze publicznej rzeczywiście grzeszy pychą i profesjonalną ekskluzywnością, przez co bardziej, jakby to ujął MacIntyre, zajmuje się „erudycyjnym definiowaniem sporów" niż ich rozwiązywaniem ${ }^{44}$. Prawa człowieka, eksponowane w niemieckiej debacie migracyjnej, to fikcje moralne, składnik oświeceniowej idei autonomicznego podmiotu moralnego. Autor Dziedzictwa cnoty w nietzscheańskim stylu ujawnia, że „fikcyjna, rzekoma racjonalność” debaty na temat tych praw $\mathrm{i}$ istoty nowoczesnej polityki „stanowi przykrywkę dla arbitralności woli i władzy, które są w niej czynnikami rozstrzygającymi" ${ }^{\prime 45}$. Jest podejrzliwy: „Kiedy ludzie nazbyt łatwo i zbyt mocno identyfikują swoje osobiste i partykularne motywy z jakąś powszechną zasadą, postępują z reguły gorzej

\footnotetext{
43 Th.W. Adorno Minima moralia. Refleksje z poharatanego życia [1951], przeł. M. Łukasiewicz, Wydawnictwo Literackie, Kraków 1999, s. 117-118 (fragment 66).

Zob. A. MacIntyre Dziedzictwo cnoty..., s. 143.
} 
niż normalnie"46. Sprawiedliwość, o którą mu chodzi, jest stanem relacji międzyludzkich wytworzonych w konkretnym miejscu i czasie („praktyki mają zawsze swoją historię" ${ }^{47}$ ) przez przygodną, ,arbitralną wolę i władzę", jej idiosynkratyczne narracje lub dyskursy, swoiste formy publicznego działania, mówienia, argumentowania i debatowania. Nie ma jednej miary sprawiedliwości, jednego złotego środka na nią. Wiąże się ona z uwolnieniem każdego człowieka od roszczeń jakiejkolwiek jedynej, , prawdziwej” racjonalności, a tym samym od strachu przed niesprostaniem tym roszczeniom, inaczej: od strachu przed różnieniem się. Nie służy jej więc wiara w prawa człowieka, w prawdy oczywiste - tatwiej ją osiagnać bez Kanta niż z nim.

A taka konkluzja na powrót odsyła nas do relacjonowanej tu debaty niemieckiej, w której udało się zabrać głos także filozofowi brytyjskiemu, Raymondowi Gaussowi. Na znane nam już pytanie redakcji „Die Zeit”, „co pozostało po Kancie?", odpowiada on mianowicie, że obsesyjne Kantowskie zajmowanie się ludzką wolnością jest „filozoficznym dziwactwem”. Jego „rozum" nie jest żadnym „, faktem”, lecz jedynie „błędnym ognikiem”, który sprowadza nas na manowce - ostatecznie „wolność" staje się okrzykiem bojowym neoliberałów: „Kto bowiem posiada 'rozum' absolutnie, przeabsolutyzowuje też własny punkt widzenia". I na zakończenie pozytywna odpowiedź, jak rozwiązać dzisiejszy problem sprawiedliwości - wskazanie na potrzebę stworzenia nowych instytucjonalnych warunków dla powszechnych rozważań nad pokojem: „Fakt, że rozważania Kanta na temat 'wiecznego pokoju' są bezużyteczne, nie jest żadnym argumentem przeciw konieczności nowej polityki pokojowej. Potrzebujemy sensownego i długotrwałego ustalenia celów dla polityki UE. Musi ona zawierać zarówno międzynarodową politykę pokojową, jak również ekologicznie uzasadnioną strategię przeżycia w wymiarze planetarnym. I to razem [z Kantem] lub (lepiej) bez Kanta"48.

Uwaga: jest tu mowa o dwóch Kantach. Ten, który stanowi przeszkodę w pomaganiu ,zwykłym ludziom”, to teoretyk abstrakcyjnego rozumu transcendentalnego, najczęściej eksploatowany w dzisiejszej debacie o uchodźcach. Ale jest też i drugi Kant, krytyk społeczny, który zakłada, że pojęcia wykorzystywane w analizie filozoficznej mogą być ucieleśnione w realnym świecie. „Nawet Kant - pisze MacIntyre - który czasami wydaje się ograniczać

\footnotetext{
46 Tamże, s. 394, 395.

47 Tamże, s. 395.

48 Was bleibt von Immanuel Kant?..
} 
sprawczość moralną do wewnętrznej dziedziny noumenalnej, w swoich pismach z zakresu prawa, historii i polityki sugeruje coś zupełnie innego"49. W tych pismach rozum nie jest już dla niego „błędnym ognikiem”, ponieważ jest zaangażowany w sprawy publiczne, stać go na uczucia, wyrażanie moralnego oburzenia, jak chociażby wobec „przerażającej” niesprawiedliwości, jaką czynią Europejczycy kolonizowanym przez siebie ludom, przynosząc im ze sobą „wojn[y], głód, rebelię, wiarołomstwo i wszystko, co jeszcze mogłaby pomieścić litania zła uciskającego ludzki rodzaj"50. Ten drugi Kant bliski jest MacIntyre'owskiej wizji krytyki filozoficznej, podejrzliwej wobec instytucji państwa, ujawniającej jego wady, interweniującej w praktykę, biorącej udział w „zwycięstwach i porażkach" codziennego życia społecznego i politycznego, wychodzącej poza dyscyplinę akademicką i status sprofesjonalizowanej teorii. W tym nowoczesnym, detektywistycznym niejako postępowaniu (na miarę Sherlocka Holmesa, stworzonego przez Szkota sir Arthura Conan Doyle'a), szkockiemu filozofowi, jak wiadomo, ma pomagać klasyczna etyka cnót - rozwijanie sprawności moralnych ma dawać szansę zwykłym ludziom na uwolnienie się z kagańca dominującej, zdaje się jedynie prawdziwej racjonalności, nastawionej na utrzymanie istniejących relacji władzy politycznej, kulturowej i społecznej. Rozwijanie cnotliwych praktyk ma pozwolić na przezwyciężenie „krzywd, niebezpieczeństw, pokus i zakłóceń"51 legitymizowanych przez nowoczesne państwo wsparte na fikcyjnych ramach pojęciowych.

Ów drugi Kant - dla pełni obrazu należałoby na zakończenie jeszcze dodać - inspiruje dziś także w omawianej dyskusji filozofię gościnności, zaprezentowaną na łamach „Die Zeit” przez Burkharda Liebscha. Zamiast etyki cnót alternatywną furtkę do wyjścia z nowoczesnego „theatrum ułudy" daje mu filozofia różnicy - zradykalizowany dyskurs inności, bezwarunkowej otwartości na roszczenia innego człowieka. Adornowska formuła o braku lęku przed różnieniem się odnosi się tu do gościnnego społeczeństwa, którego zrozumienie ma pozwalać „na nowo odkryć najstarszy i najbardziej źródłowy sens kultury ludzkiej w ogóle"52. Ten sens Jacques Derrida utożsamił z samą kulturą: chodzi mianowicie o prastare prawo, które nakazuje przyjmowanie pod dach przybyszów-wędrowców w potrzebie i równoczesne

49 A. Maclntyre Dziedzictwo cnoty..., s. 60.

50 I. Kant Do wiecznego pokoju. Projekt filozoficzny, s. 66.

51 A. Maclntyre Dziedzictwo cnoty..., s. 391.

52 B. Liebsch Flüchtlingshilfe: Unser Land überrascht sich selbst, „Die Zeit” 18 September 2015. 
nielegitymowanie ich na progu domostwa. W opisie zjawiska gościnności, jaki proponuje francuski filozof, pojawia się postać pana domu, który „czeka, nie czekając”, „nie wiedząc, na kogo czeka"53 - nie wiedząc zatem także, czym jest sama gościnność. „Prawo gościnności” odnosi się dlatego do stanu naszej niewiedzy - zawsze „jeszcze nie wiemy”, czym ona jest, w tym sensie "prawo" to jest wewnętrznie sprzeczne, znajduje się jakoś „ponad prawem”, jako systemem prawa narodowego czy międzynarodowego. Liebsch wnosi stąd, że bez momentu gościnności niczym nieuwarunkowanej, to znaczy niegwarantowanej ani prawem, ani etyką, nieopierającej się na przepisach, normach czy regułach, życie kulturalne zamienia się w grę produkcji obiektów kulturowych, i w całym swym bogactwie staje się ostatecznie zbyteczne $e^{54} . \mathrm{Na}$ łamach gazety zawęża tę uwagę do polityki i dochodzi do wniosku, że:

Kultura polityczna, która godziłaby się z niegościnnymi na całym świecie warunkami życia, nie zasługuje na swoją nazwę. Jej bogactwo byłoby jedynie najbardziej widoczną manifestacją jej bezgranicznej społecznej biedy. ${ }^{55}$

MacIntyre'owi wystarczą do tego celu cnotliwe praktyki i racjonalna argumentacja, które mają stworzyć przestrzeń publiczną inkluzyjną, otwartą na przybyszów, innych i obcych. Mają angażować naraz nasz intelekt, wrażliwość i wyobraźnię, po to, by otworzyć nas na zrozumienie przybyszów - ich idiosynkratycznych opowieści o świecie, i na wspólne z nimi życie możliwie wolne od relacji dominacji i panowania jednych nad drugimi.

Może więc między tymi rozmaitymi filozoficznymi drogami wyjścia poza nowoczesny świat fikcji, zamieszkały przez ludy osiadłe i pewnych siebie gospodarzy, jakie proponują teoria krytyczna, filozofia różnicy oraz etyka cnót w wydaniu MacIntyre'owskim, mielibyśmy tylko do czynienia z różnicami na poziomie retoryki, a nie sensu? Może wszystkie te podejścia łączy jedno, jawnie lub ukrycie przyjmowane, założenie, według którego w życiu etyka idzie przed ontologią, sprawiedliwość przed prawdą i wolnością. I oparte na tym

53 J. Derrida Wrogościnność, przeł. A. Dwulit, w: Wrogościnność. Podejmowanie obcych. Katalog wystawy, Muzeum Sztuki w Łodzi 2010, s. 15.

B. Liebsch Spielräume einer Kultur der Gastlichkeit. Zwischen Ethik, Recht und Politik (Teil 2) , "Philosophische Rundschau" 2015 Nr. 62, s. 258-260. Zob. też w tym samym tomie pierwszą część tego artykułu.

\section{B. Liebsch Flüchtlingshilfe: Unser Land überrascht sich selbst.}


założeniu przekonanie, że filozofia, chcąc nie chcąc, uwikłana jest w publiczny spór o sprawiedliwość, której źródła nie są ulokowane w abstrakcyjnych prawach, lecz w obcowaniu z konkretnymi ludźmi, wolnymi od upokorzeń przez innych i uprawnionymi do wyboru swojego miejsca na Ziemi.

\section{Abstract}

\section{Jan P. Hudzik}

MARIA CURIE-SKŁODOWSKA UNIVERSITY, LUBLIN

Philosophy and the Refugee Problem in Germany

The latest public debate over refugees in Germany focuses on issues such as the relations between the nation and modern multi-ethnic society, the state and other institutions and their responsibilities to protect human rights, as well as feelings of anxiety and fear produced by cultural otherness. Hudzik presents a selection of critical voices in this debate, considering the relevance of social philosophy from a hermeneutic point of view, its critical power to interfere with the public sphere and the politics of the state. Hudzik also invokes Maclntyre's notion of the relationships between theory and practice, as well as his idea of critical thinking. The starting point for the German discussion is Kant's practical philosophy, which includes his understanding of the human rights of refugees.

\section{Keywords:}

refugees, Germany, critical philosophy, human rights, hospitality, identity discourse 